\title{
Role Theory and Securitization: An Agency Based Framework for Decoding Turkey's Diplomatic Offensive against Israel
}

\author{
Şevket Ovalı * \\ Yücel Bozdağlığlu**
}

\begin{abstract}
Turkish foreign policy has recently undergone remarkable changes, and these changes have led to a considerable degree of foreign policy activism, most notably in the Middle East, which has never been seen throughout the history of the Turkish Republic. It is unquestionable that Turkey's activism in the Middle East increased the country's power in the Arab-Muslim political circles but also caused deterioration in Turkish-Israeli relations. Although there has been a consensus on relating the changes in Turkish foreign policy towards the Middle East with the Justice and Development Party's (Adalet ve Kalkinma Partisi, AKP) leading echelons, to date only a few studies attempted to incorporate a particular theoretical approach to explain this agency based shift. This paper argues that role theory can be incorporated into the theory of securitization and it can be used as a conceptual tool for decoding Turkey's strained relations with Israel.
\end{abstract}

\section{Keywords}

Turkish Foreign Policy, Israel, Securitization

\footnotetext{
*Şevket Ovalı, $\mathrm{PhD}$, is an assistant professor in Dokuz Eylül University, İzmir, Turkey.

${ }^{* *}$ Yücel Bozdağhlığlu, $\mathrm{PhD}$, is an associate professor in Adnan Menderes University, Nazilli, Turkey.
} 


\section{Introduction}

In the past decade, Turkey's foreign policy has experienced a dramatic reorientation "from a long-entrenched passive and isolationist stance to one of active engagement particularly in the affairs of the Middle East". ${ }^{1}$ AKP's contribution to this new orientation raised eyebrows in secular, Kemalist circles in Turkey and in the West due to the Islamic background of the party leaders. Some observers noted that Turkey's increasing interest in Middle Eastern affairs, especially in the Palestinian issue, signaled an axis shift in Turkey's foreign policy, and that "Turkey's foreign policy has increasingly been Middle Easternizing".

AKP leaders' intimate association with the Hamas (Palestinian Islamic Resistance Movement) leadership and subsequent deterioration of Turkish-Israeli relations further increased concerns. The crisis in Turkish-Israeli relations became apparent when Turkey's Prime Minister, R. Tayyip Erdoğan, stormed off the stage at the World Economic Forum in Davos after a heated debate on Gaza with Israel's president, Shimon Peres, in 2009. The more serious crisis came in June 2010 when Israeli commandos stormed a Turkish aid flotilla, Mavi Marmara, that attempted to break the Israeli-imposed blockade on Gaza controlled by Hamas, killing nine (eight Turkish citizens and one American citizen of Turkish origin) and wounding many others on

\footnotetext{
1 Bülent Aras and Aylin Görener, "National Role Conceptions and Foreign Policy Orientation: The Ideational Bases of the Justice and Development Party's Foreign Policy Activism in the Middle East," Journal of Balkan and Near Eastern Studies, Vol.12, No.1 (March 2010), p.73.

${ }^{2}$ Tarık Oğuzlu, "Middle Easternization of Turkey's Foreign Policy: Does Turkey Dissociate from the West?" Turkish Studies, Vol.9, No.1 (2008), p.3.
} 
Decoding Turkey's Diplomatic Offensive against Israel

board. While "Israel described the incident as normal self-defense, Turkish statesmen called it as act of 'piracy,' 'murder by a state' and 'state terrorism"'.

The crisis between Turkey and Israel was further complicated by the statements of some AKP's top echelons who linked the outlawed Kurdistan Workers' Party's (PKK) terrorist attacks to Israel implying that Israel might be behind those terrorist attacks. Given that terrorism is a very sensitive national security issue for Turkey, those statements constituted Israel as a threat to Turkey's national security and territorial integrity. Especially when Israeli army's attack on the Mavi Marmara flotilla took place, AKP officials started to strongly voice their concerns about Israel's support for PKK activities. As we will empirically demonstrate throughout our study, the AKP constructed Israel as a threat not only to Turkey's national security but also to Muslims and the Islamic value system. This takes us to the argument that ideology and identity concerns played a major role in the AKP's securitization of Israel which, according to us, requires paying more attention to agency in analyzing Turkey's strained relations with Israel.

We argue that role theory can be incorporated into the theory of securitization and it can be used as a conceptual tool in explaining sources of leaders' threat perceptions, which constitute the first step in securitization. For this purpose, this article is organized as follows: In the first section of the article, we introduce the relevant aspects of the securitization theory namely, the role of the securitizing actor. The second part of the paper attempts to incorporate the role theory into the securitization theory and argues that leaders' national role

${ }^{3}$ Hasan Kösebalaban, "The Crisis in Turkish-Israeli Relations: What is the Strategic Significance?” Middle East Policy, Vol.17, No.3 (2010), p.37. 
conceptions (NRCs) can serve as an important foundation upon which the securitization theory can be built. The third section examines traditional Republican perceptions about Israel and Arab states and aims to reveal the change after Islamists began to emerge as the dominant political power in Turkish politics. The final part analyzes the recent downward turn in Turkish-Israeli relations and Turkish leaders' attempts to present Israel as an existential threat from the NRC-securitization perspective.

\section{Securitization Theory and the Significance of Agency}

The end of the Cold War and subsequent developments in the international system sparked new discussions, among many other things, on the viability of traditional IR theories, most specifically Realism in explaining international security problems. The theory of securitization developed by Barry Buzan and Ole Wrver, whose works are collectively called as the Copenhagen School (CS), has made one of the most important and, perhaps, the most controversial contributions to the security studies literature. Inspired by the works of J. L. Austin and John R. Searle $^{4}$, the CS argues that securitization is indeed a speech-act through which a securitizing actor or actors can identify something as an existential threat to a valued referent object and call for extraordinary measures to deal with that threat. ${ }^{5}$ The CS argues that, understood this way, "securitization can thus be seen as a more extreme version of politicization", which can be extended

${ }^{4}$ John Langshow Austin, How to Do Things with Words (London: Oxford University Press, 1962), John Searle Expression and Meaning: Studies in the Theory of Speech Acts (New York: Cambridge University Press, 1979).

${ }^{5}$ Barry Buzan, Ole Waever and Jaap De Wilde, Security: A New Frameworke for Analysis (Boulder \& London: Lynne Rienner Publishers, 1998), p.21.

${ }^{6}$ Ibid., p.24. 
Decoding Turkey's Diplomatic Offensive against Israel

beyond traditional military issues including the environment, society and economic sectors.

The CS argues that "securitization is intersubjective and socially constructed" and successful securitization is decided by the audience. ${ }^{7}$ In this regard, the theory of securitization is marked by three elements: the speech act, the securitizing actor and the audience. ${ }^{8}$ This approach, argues Stritzel, "splits the actor into two elements: the securitizing actor performing a securitizing move by uttering a speech act, and a relevant audience accepting or refusing this move". "The CS defines a securitizing actor as "someone, or a group, who performs the security speech act. Common players in this role are political leaders, bureaucracies, governments, lobbyists" ${ }^{\prime 10}$ depending on the nature of the referent object. It is the actor who decides whether something constitutes and therefore, should be handled as an existential threat. The main condition for someone to be a securitizing actor is that he or she should be in "a position of authority" to decide whether an issue takes priority over others.

The securitizing actor has a significant place in securitization analysis but its role is not examined thoroughly by the CS. The theory of securitization was elaborated and criticized by various scholars ${ }^{12}$, which will not be reiterated here. Instead, we

${ }^{7}$ Ibid, p.31.

${ }^{8}$ Holger Stritzel, "Towards a Theory of Securitization: Copenhagen and Beyond," European Journal of International Relations, Vol.13, No.3 (September 2007), p.362.

${ }^{9}$ Ibid., p.363.

${ }_{10}$ Buzan et al., p.40.

${ }^{11}$ Ibid., p.32.

12 See: Matt McDonald, "Securitization and the Construction of Security," European Journal of International Relations, Vol.14, No.4 (2008), pp.563-587. Michael Williams, "Words, Images, Enemies: Securitization and International Politics," International Studies Quarterly, Vol.47, No.4 
focus on the agency side of the securitization theory and argue that the CS that puts more emphasis on the intersubjective side of the theory. If this is the case, any theory of securitization must pay greater attention to the subjective side of securitization and illustrate how securitizing actors define an existential threat. In other words, what makes something an existential threat for the securitizing actor who discursively transmits his perception of the threat to people, which may or may not accept it as such, should be explicated.

If security threats are subjective phenomena then how actors define those threats and the choice of a particular referent object become important for security analyses. For the CS, the actor, definition of an existential threat and the referent object are important elements of the securitization theory, but there is not an adequate analysis about the sources of these elements. How do actors define threats? Why does an issue but not others take priority for the securitizing actor? These and related questions can be answered by incorporating the role theory into the theory of securitization, which we will turn in the following section.

\section{Integrating Role Theory into Securitization}

Role theory, initially developed in sociology and psychology to understand the behavior of individuals, was adopted by foreign policy scholars to understand and explain a state's foreign policy behavior. K. J. Holsti was the first to incorporate

(2003), pp.511-531. Thierry Balzacq, "Three Faces of Securitization: Political Agency, Audience and Context," European Journal of International Relations, Vol.11, No.2 (2005), pp.171-201. Thierry Balzacq, "Constructivism and Security Studies," in Myriam Dunn Cavelty and Victor Mauer (eds.), The Routledge Handbook of Security Studies (London and New York: Routledge, 2010), pp.56-72. 
Decoding Turkey's Diplomatic Offensive against Israel

role theory into Foreign Policy Analysis (FPA) by studying role conceptions and their impact on a state's international behavior. ${ }^{13}$ According to role theory, actors identify their nation with particular roles and act in accordance with the expectations and demands that roles generate. Thus, role theory assumes that states behave consistently with specific roles with which they identify. ${ }^{14}$

Holsti defined many roles for states arguing that states perform those roles in the international system and used role performance, role conceptions and role prescriptions as different analytical tools to categorize state behaviors. Role performance refers to "the general foreign policy behavior of governments and it includes patterns of attitudes, decisions, responses, functions and commitments toward other states". ${ }^{15}$ Role conceptions, on the other hand, include

the policymakers' own definitions of the general kinds of decisions, commitments, rules, and actions suitable to their state, and of the functions, if any, their state should perform on a continuing basis in the international system or subordinate regional systems. It is their image of the appropriate orientations or functions of their state toward, or in, the external environment. ${ }^{16}$

In other words, role conceptions "encompass both an actor's own consideration of its place, position, and appropriate behavior vis-à-vis others in a given social environment and the

\footnotetext{
${ }^{13}$ Kalevi J. Holsti, "National Role Conceptions in the Study of Foreign Policy," International Studies Quarterly, Vol.14, No.3 (1970).

${ }^{14}$ Richard Adigbuo, "Beyond IR Theories: The Case for National Role Conceptions," Politikon, Vol.34, No.1 (2007), p.88.

${ }_{15}$ Kalevi J. Holsti, "National Role Conceptions in the Study of Foreign Policy," in Stephen G. Walker (ed.), Role Theory and Foreign Policy Analysis (Durham: Duke University Press, 1987), p.12.

${ }^{16}$ Ibid.
} 
expectations or role prescriptions of other actors as signaled through language and action".17

Finally, Holsti defines role prescriptions, which are understood as "the norms and expectations cultures, societies, institutions, or groups attach to particular positions". ${ }^{18}$ The structure of the international system, system-wide values, rules, norms or traditions, expectations of other states, treaties, and more generally common understandings in the system can serve as the sources of role prescriptions. To put it differently, role prescriptions constitute the external sources of roles.

Even though role theory allows analyses at individual, state and systemic levels, and provides an essential methodological and epistemological tool to FPA scholars, its use in the academia waned over the years. With the emergence of constructivism in the USA, many IR theorists started to make use of roles and aspects of role theory. ${ }^{19}$ Many constructivist IR scholars, most prominently Alexander Wendt, adopted a structural approach to roles and so diverged from FPA scholars that favored the cognitive approach. In Wendt's systemic analysis, state identities and consequently interests are thought to be formed through systemic

\footnotetext{
${ }_{17}$ Rikard Bengtsson and Ole Elgström, "Conflicting Role Conceptions? The European Union in Global Politics," Foreign Policy Analysis, Vol.8, No.1 (January 2012), p.93.

${ }^{18}$ Holsti (1970), p.239.

19 Cameron Thies and Marijke Breuning, "Integrating Foreign Policy Analysis and International Relations through Role Theory," Foreign Policy Analysis, Vol.8, No.1 (January 2012), p.2.
} 
Decoding Turkey's Diplomatic Offensive against Israel

interaction. ${ }^{20}$ This approach ignores domestic cultural factors and leaders' belief systems that shape the formation of roles. ${ }^{21}$

A cognitive approach to role analysis provides us with both an analytical and operational link between identity constructions and patterns of foreign policy behavior. The utility of role theory lies in its emphasis on subjective factors -i.e., the importance of cognitive aspects of individuals involved in the formulation of foreign policy. This way, the subjective environment in which individual decision makers make their decisions is made problematic and "in doing so calls our attention to the world as perceived and represented by those actors involved in foreign policy decision making processes. ${ }^{22}$ This cognitive analysis also helps explain the link between role conceptions held by decision makers and the securitization of an issue because it directs our attention to the 'importance of 'worlds' as they are perceived and constructed by individual decision makers and suggests that 'objective' reality is not the locus of meaning and therefore not the key to understanding political behavior and practices. Rather, individuals are the source of meaning". ${ }^{23}$

Since the securitization of an issue starts with the securitizing actors' subjective understanding of the world and threats perceived in that world, any analysis of a security issue

${ }^{20}$ See: Alexander Wendt, Social Theory of International Politics (Cambridge: Cambridge University Press, 1999).

21 For further critique of structural approach see Jutta Weldes, "Constructing National Interest," European Journal of International Relations, Vol.2, No.3 (September 1996). Thomas Banchoff, "German Identity and European Integration," European Journal of International Relations, Vol.5, No.3 (September 1999).

22 Roxanne Lynn Doty, "Foreign Policy as Social Construction: A PostPositivist Analysis of U.S. Counterinsurgency Policy in the Philippines," International Studies Quarterly, Vol.37, No.3 (1993), p.300.

${ }^{23}$ Ibid. 
from the perspective of the CS should start with role conceptions/identities of decision makers. Discursive practices of securitizing actors are often the expressions of their role conception and they linguistically construct reality. In other words, securitization is meaning creation and "the meanings which objects, events and actions have for states" are necessarily the meanings they have for those individuals who act in the name of the state". ${ }^{24}$ Therefore, it can be argued that there is a close connection between leaders' role conceptions and their perception of threat because "policy makers also function within a discursive space that imposes meanings on their world and thus creates reality". ${ }^{25}$ As Weldes argues,

These state officials do not approach international politics with a blank slate on which meanings are written only as a result of interactions among states. Instead, they approach international politics with an already quite comprehensive and elaborate appreciation of the world, of the international system and of the place of their state within it. This appreciation, in turn, is necessarily rooted in meanings already produced, at least in part, in domestic political and cultural contexts. ${ }^{26}$

These meanings that individual decision makers hold for their state and others in the international system consequently construct leaders' role conceptions and they, therefore, are part of national identity. Leaders as individuals are socialized in that national identity context, which in turn shape their subjective role conceptions. These role conceptions or meanings help work as "road maps" that guide foreign policy makers in understanding a

\footnotetext{
${ }^{24}$ Weldes (1996), p.280.

${ }_{25}$ Doty (1993), p.303.

${ }^{26}$ Weldes (1996), p.280.
} 
Decoding Turkey's Diplomatic Offensive against Israel

complex political reality. ${ }^{27}$ Role conceptions, which are formed through various linguistic and cultural resources, also help decision makers create representations "which serve, first, to populate the world with a variety of objects, including both the self (i.e., the state in question) and others. Each of these objects is simultaneously given an identity; it is endowed with characteristics which are sometimes precise and certain, at other times, vague and unsettled". ${ }^{28}$ This is because through role conceptions, leaders position their states in the international system vis-à-vis other states and determine their in-group/out-group members. This necessarily means that they define first, themselves, their friends and enemies long before systemic interaction through representations which are produced in large part in domestic political and cultural contexts. These representations also provide "warranting conditions which make a particular action or belief more 'reasonable', 'justified', or 'appropriate', given the desires, beliefs, and expectations of the actors. In providing warranting conditions, they help to specify, among other things, which objects are to be protected and which constitutes threats". ${ }^{29}$

It is worth noting that since role conceptions/identities are subjective phenomena, a multitude of role conceptions can exist in a society. Which role conception will dominate the foreign policy discourse and behavior is a matter of domestic power struggles between different political actors with different role conceptions. Changes in domestic power configuration through either democratic (elections) or forceful (revolutions) developments can alter the role of domestic political groups and consequently "the foreign policy discourse can be dominated by entirely new

${ }^{27}$ For the role of ideas on the foreign policy changes see Joshua Goldstein and Robert Keohane (eds.), Ideas and Foreign Policy: Beliefs, Institutions and Political Change (New York: Cornell University Press, 1993).

${ }^{28}$ Weldes (1996), p.300.

${ }^{29}$ Ibid., p.284. 
organizations or individuals with different identity conceptions". ${ }^{30}$ The new official discourse then shapes the foreign policy orientations of the state. In this regard, the following section seeks to demonstrate the perceptions of traditional republican-secular foreign policy elite about the Arabs and Israelis in order to analyze the rupture that has become prominent with the rise of political Islam in Turkish politics.

\section{Arab and Israeli Images among the Foreign Policy Elites}

In order to better understand the impact of the current ruling elite's national role conceptions on the transformation of Turkey's foreign policy, one needs to analyze the historical and discursive roots of the AKP's stance toward the Middle East and Israel. Before clarifying the AKP elite's NRCs and examining how they are linked to specific foreign policy orientations, we should first explore the foreign policy preferences of the Republican elite who have set the principles of traditional Turkish foreign policy.

States' foreign policy preferences are largely shaped by the political, cultural and personal characteristics of the founding elites. ${ }^{31}$ The basic principles of Turkish foreign policy were firmly established by M. Kemal Atatürk, who founded the Turkish Republic in 1923. In order to create a new state and a society in line with those of the West, Atatürk embarked on a massive modernization project that also reflected upon the content and major orientation of foreign policy. For Turkish modernizers, modernization meant westernization- "taking a place in the

30 Yücel Bozdağlıŏlu, Turkish Foreign Policy and Turkish Identity: A Constructivist Approach (London and New York: Routledge, 2003), p.25.

31 Aras and Görener (2010), p.78. 
Decoding Turkey's Diplomatic Offensive against Israel

civilization of Europe". ${ }^{32}$ Their understanding of western civilization was that of "Western Europe", especially France and Britain. Modernity, in their conception, was a project of "embracing and internalizing all the cultural dimensions that made Europe modern". ${ }^{33}$ In order to achieve secularization and autonomy for the individual, simply increasing rationality, bureaucratization, and organizational efficiency were not enough; a complete social and cultural transformation was needed. The understanding of modernization in this way required the "negation of a universal framework: Islam" ${ }^{34}$ that had provided the state with political legitimacy and individuals with an identity during the Ottoman Empire. "The society withdrew from the Islamic framework into that of the newly-defined Turkish nation... The Turkish revolution rejected completely the religious basis of legitimation and attempted instead to develop a secular national one as the major ideological parameter of the new collectivity". ${ }^{35}$

Accordingly, westernization had profound repercussions in the foreign policy domain. The Republican elite and the military that were given a privileged position in the formulation of foreign policy "held onto a Western-oriented, isolationist and passive foreign policy stand, while effectively excluding mass society from

32 Çağlar Keyder, "Wither the Project of Modernity: Turkey in the 1990s," in Reşat Kasaba and Sibel Bozdoğan (eds.), Retbinking Modernity and National Identity in Turkey (Seattle: University of Washington Press, 1997), p.37.

33 Ibid.

34 Samuel N. Eisenstadt, "The Kemalist Regime and Modernization: Some Comparative and Analytical Remarks," in Jacob M. Landau (ed.), Ataturk and Modernization of Turkey (Boulder, CO: Westview Press, 1984), p.9.

35 Samuel N. Eisenstadt, "The Kemalist Revolution in Comparative Perspective," in Ali Kazancigil and Ergun Özbudun (eds.), Ataturk: Founder of a Modern State (Hamden: Archon Books, 1981), p.135. 
constructing alternative conceptions". ${ }^{36}$ The modernization and westernization process, which constitute the raison d'être of the Republican regime, "required that interaction with the Middle East to be kept to a minimum". ${ }^{37}$ In the official Republican discourse, the adjectives "the untrustworthy Arab and the uncivilized, backward Arab states governed by Sharia law..."38 were often used as warranting conditions to legitimize the Republic's disenchantment with the Middle East and Islamic civilization. Additionally, references to the "betrayal of the Arabs" during World War I served to create a negative image of the Arabs. As a result, the gap between Turkey and the eastern Islamic world widened.

On the contrary to this negative Arab image, the Republican elite viewed the Jews living in the country rather favorably. The creation of Israel in 1948 was a turning point in these relations. Even though Turkey originally opposed the partition of Palestine in 1947 due to the fear of a communist takeover in that country, it was the first Muslim country to recognize Israel at the expense of her relations with the Arabs.

It must be stressed that Turkey's close ties with Israel were the by-product of her relations with the Arabs and the West. From 1949 to 1963 , Turkey perceived Israel mainly as a "country which achieved rapid modernization and progress in a relatively underdeveloped area. Thus, the Israeli educational and industrial establishment, the dynamism of her people became the subject of

\footnotetext{
36 Aras and Görener (2010), p.78.

${ }^{37}$ Hakan M. Yavuz, "Turkish-Israeli Relations through the Lens of the Turkish Identity Debate," Journal of Palestine Studies, Vol.27, No.1 (Autumn 1997), p.23.

38 Mahmut Bali Aykan, "The Palestinian Question in Turkish Foreign Policy from the 1950s to the 1990s," International Journal of Middle Eastern Studies, Vol.25, No.1 (February 1993), p.92.
} 
Decoding Turkey's Diplomatic Offensive against Israel

envy and admiration in the Turkish press". ${ }^{39}$ Turks often compared Israel's achievements with the failures of the Arabs. As Mim Kemal Öke points out, "looking down on Arabs even brought in its train rather praising evaluations of Israel's 'miracles.' Israel's military victories against her Arab neighbors and the various development projects she had successfully undertaken were readily applauded in Turkey by some republican circles". ${ }^{40}$ The admiration for Israel immediately reminded the Turks of the stereotype of the untrustworthiness and laziness of the Arabs and of their betrayal to the Ottoman Empire.

During the Cold War, Turkey's relations with Israel grew closer. Even Turkey's pro-Arab policy during the 1970s and the 1980s did not lead to a complete break-up of her relations with Israel despite the pressure from the Arabs. Although Turkey often publicly condemned Israel's actions towards the Palestinians, voted along with the Arabs at the UN, and kept her diplomatic representation in Tel-Aviv to chargé d'affaires level, these actions were never strong enough to break off Turkish-Israeli relations altogether.

The close relations between Turkey and Israel grew into strategic partnership in the 1990s, mainly led by the Turkish military, and resulted in a series of agreements in the areas of free trade, culture, tourism and, most importantly, military training. In August 1996, Prime Minister and the leader of the Islamic Welfare Party (Refah Partisi, RP), Necmettin Erbakan, signed a military agreement with Israel, mainly due to the pressure from the military, that involved a $\$ 590$ million deal in which the Israeli

39 Kemal Karpat, "Turkish and Arab-Israeli Relations," in Kemal Karpat (ed.), Turkish Foreign Policy in Transition, 1950-1974 (Leiden: E.J. Brill, 1975), p.114.

${ }^{40}$ Mim Kemal Öke, "Arabic Studies in Turkey: Themes, Approaches and Sources," Studies on Turkish-Arab Relations, Vol.2 (1987), p.49. 
Aircraft Industries would modernize Turkey's F-4 Phantom fighters with high-tech equipment. It is important to note that Necmettin Erbakan, who adopted an anti-Israel and anti-Western political discourse, had to succumb to the pressure from the military, the guardian of Kemalist principles. The most significant figure of political Islam in Turkey, Erbakan had promised throughout his election campaign to cut off ties with Israel, and when the initial agreements became public in April 1996, Erbakan and the prominent figures of RP "vowed to scrap it when they came to power". ${ }^{41}$ However, when Erbakan became prime minister in June 1996, Turkey and Israel completed the final part of the agreements. The same military that identified Islamic fundamentalism and Kurdish nationalism as the main threats to Turkey's national security, forced him to resign after a militarydominated National Security Council meeting on February 28, 1997.

The tension between Erbakan and the Turkish military was also apparent in foreign policy preferences of the two actors. For the military, Turkey was a Western country and Turkey's relations with Israel should have been conducted in terms of the latter's perceived Western identity. Even though there are reasons to believe that the Kemalist establishment in Turkey and Israel acted for self-interested reasons, it is also true that their interests were linked to their mutual identities. During the 1990s, when the relations started to improve between the two countries, "a mutual image was created by both sides that was used to portray a 'self' and an 'other' as being distinct" ${ }^{\prime 2}$ in the region dominated mainly by Arab states. When the rapprochement between Turkey and

${ }^{41}$ Sabri Sayari, "Turkey and the Middle East in the 1990s," Journal of Palestine Studies, Vol.26, No.3 (Spring 1997), p.49.

${ }^{42}$ Anat Lewin, "Turkey and Israel: Reciprocal and Mutual Imagery in the Media, 1994-1999," Journal of International Affairs, Vol.54, No.1 (2000), p.239. 
Decoding Turkey's Diplomatic Offensive against Israel

Israel became public, the Turkish press and the political elite that advocated such a relationship with Israel emphasized the notion that Israel and Turkey are the only countries in the region that share a common identity (i.e., Western) and that Turkey has a lot to gain from this relationship.

Erbakan, on the other hand, had different role conceptions, and consequently different foreign policy preferences. His Islamic ideology led him to advocate closer relations with the Muslim Middle Eastern countries and to cut off relations with Israel. He adopted a strong anti-Western and anti-Israeli stand and defined Israel as the most dangerous threat to the Muslim cause. He often blamed Zionism and Israel for the problems of Turkey. As part of his political discourse, he and his followers often used the religious term "the Jewish State" rather than political or strategic terms in describing Israel. In his representation of Israel, the term "the Jewish state" was persistently articulated and thus came to connote the "enemy of Islam", "threat", "terrorist", "aggressor" or "murderer" for the Islamists. During his short stint in power, he tried to realize his ambition of Turkey as the leader of the Islamic world and visited such radical states as Iran and Libya to mend the fences but the Kemalist elite and the military would not let him deviate from Western-oriented foreign policy.

In the light of the above discussion, we argue that the reorientation of Turkey's foreign policy toward the Middle East and the recent crisis in Turkish-Israeli relations, which even led the AKP leadership to describe Israel as an "existential security threat", can be attributed to the Islamic identity and related NRCs of the AKP's foreign policy elite. 


\section{Turkey's NRCs and AKP's Securitization of Israel}

When the Constitutional Court shut down the RP, Erbakan was banned from active politics. Even though the party reappeared under different names (Virtue Party, later Felicity Party) it never had its former electoral strength. First the current president Abdullah Gül and later the current prime minister Recep Tayyip Erdoğan left the party and established the Justice and Development Party (AKP) in 2001 and came to power in 2002 elections. After winning landslide victories in two consecutive elections in 2007 and 2011, the AKP came to dominate both domestic and foreign policy of Turkey.

Even though the AKP emerged within the RP and the party leaders once adopted the RP's National Outlook view, later, they renounced this ideology saying that the AKP is not an Islamic but a conservative democrat party. The party leaders also espoused an accommodative approach with the Kemalist establishment and followed a pro-EU policy. However, after the second electoral victory in 2007, the AKP took more radical steps especially in civilmilitary relations and transformed domestic politics. ${ }^{43}$ Critics argued that the AKP had never left the National Outlook but waited for the appropriate time to put its Islamic program in action.

The transformation of Turkish foreign policy especially under the new foreign minister, Ahmet Davutoğlu, was remarkable. Davutoğlu, who had previously been Prime Minister Recep Tayyip Erdoğan's chief advisor for foreign policy and who was later appointed as the minister of foreign affairs in 2009, transformed Turkish foreign policy to an extent that was

\footnotetext{
43 S Sevket Oval1, "Revisiting the Turkish Identity Debate in Turkish Israeli Relations," Journal of South Asian and Middle Eastern Studies, Vol.35, No.4 (Summer 2012), p.49.
} 
Decoding Turkey's Diplomatic Offensive against Israel

inconceivable a decade ago. Being the intellectual architect of Turkey's new foreign policy orientation, Davutoğlu was associated with the increasing activism in a number of foreign policy issues. ${ }^{44}$ This activism is more apparent in Middle Eastern affairs, especially in the Israeli-Palestinian conflict.

Even though the AKP expressed a strong pro-EU stance in the first years of its rule, its enthusiasm in EU membership has waned over the years. ${ }^{45}$ Instead, the Middle East and the Palestinian issue started to occupy the center stage in AKP's foreign policy discourse. The emphasis on the Palestinian issue often carried religious/Islamic connotations, which inevitably put Turkey against Israel. We argue that after the gradual elimination of the Kemalist rivals, especially the military, from the political life, the AKP's foreign policy elite had "an uncontested authority to orient Turkish foreign policy in line with their role conceptions" which often conflicted with those of Israeli political elite.

After an extensive analysis of speeches and the transcripts of the interviews with the AKP foreign policy makers, including Prime Minister R. Tayyip Erdoğan, Foreign Minister Ahmet Davutoğlu, and other AKP officials, we argue that three particular roles, namely "regional leader", "regional protector" and "defender of Islam", paved the way for Turkish-Israeli confrontation.

\footnotetext{
${ }^{44}$ Aras and Görener (2010), p.81.

45 For AKP's discourse and policy orientations on Turkey's bid for European Union membership see Ali Resul Usul, "The Justice and Development Party and the European Union: From Euro-Skepticism to Euro-Enthusiasm and Euro-Fatigue," in Ümit Cizre (ed.), Secular and Islamic Politics in Turkey: The Making of the Justice and Development Party (New York: Routledge, 2008), p.175-198.

46 Aras and Görener (2010), p.81.
} 
In Holsti's typology, "regional leader" as a NRC refers to "duties and special responsibilities that a government perceives for itself in its relations to states in a particular region". ${ }^{47}$ In the official discourse of the AKP leadership, the constant articulation of Turkey as a "regional leader" indicates that the foreign policy orientation of the AKP has a very strong regional emphasis. According to Davutoğlu's "Strategic Depth" doctrine, the regional leadership role encompasses two important elements: geographical and historical. Geographically, Davutoğlu states,

Turkey occupies a center of attraction in its region; its cultural capital, İstanbul, spans two continents and is at once a Middle Eastern, Black Sea and a Mediterranean city. In terms of its area of influence, Turkey is a Middle Eastern, Balkan, Caucasian, Central Asian, Caspian, Mediterranean, Gulf, and Black Sea country. Given this picture, Turkey should make its role of a peripheral country part of its past and appropriate a new position: one of providing security and stability not only for itself, but also for its neighboring regions. Turkey should guarantee its own security and stability by taking on a more active, constructive role to provide order, stability and security in its environs..$^{48}$

Davutoğlu's vision of Turkey as a regional leader also has historical roots that go back to the Ottoman rule in the region. In his words,

Countries like Turkey, China and Japan have deep historical roots in their regions...During the transit from the $19^{\text {th }}$ to the $20^{\text {th }}$ century; there were eight multinational empires across Eurasia: Britain, Russia, Austria-Hungary, France, Germany, China, Japan and Turkey. Now these countries are experiencing very similar problems with their prospective

\footnotetext{
${ }^{47}$ Holsti (1970), p.261.

48 Ahmet Davutoğlu, “Turkey's Foreign Policy Vision: An Assessment of 2007," Insight Turkey, Vol.10, No.1 (2007), p.79.
} 
Decoding Turkey's Diplomatic Offensive against Israel

regions. As these countries possess historical depth they form spheres of influence; if they fail to do this they then experience various problems. ${ }^{49}$

Ahmet Davutoğlu's "strategic depth" perspective envisions Turkey as a "central country" located at the core of the AfroEurasian landmass. Turkey, Davutoğlu said, "resting on both its geopolitical position and Ottoman heritage, had to resume a leading role in the Middle East and the Muslim world at large". ${ }^{50}$ This vision inspired by both geographical and historical factors carries with it a strong "neo-Ottomanist" flavor. As Richard Falk argues:

Davutoğlu represents a new cultural and political trend in Turkey associated with a deliberate revival of the Ottoman past, both as a matter of cultural enrichment, but also as a source of an enriched Turkish identity as a political actor. What Davutoğlu particularly celebrates is what he calls the "accommodative" character of the Ottoman Empire in its height, that is, the willingness to appreciate and respect civilizational and ethnic diversity, and to deal with political conflict in a spirit of compromise and reconciliation. ${ }^{51}$

Turkey's new activism in the Middle East made a clash of interests with Israel inevitable because the AKP's ambition for Turkey as the regional leader also overlaps with "regional protector role" that "places emphasis on the functioning of providing protection for adjacent regions". 52 Tayyip Erdoğan underlines Turkey's responsibility to protect Muslim communities in the

\footnotetext{
${ }^{49}$ Quoted in Aras and Görener (2010), p.82.

50 David Kushner, "Before and Beyond the 'Freedom Flotilla': Understanding Turkish-Israeli Relations," Israel Journal of Foreign Affairs, Vol.4, No.3 (2010), p.24.

${ }^{51}$ Quoted in Ahmet Sözen, "A Paradigm Shift in Turkish Foreign Policy: Transition and Challenges," Turkish Studies, Vol.11, No.1 (2010), p.108.

${ }^{52}$ Holsti (1970), p.262.
} 
adjacent territories by pointing out the underlying causes of Turkey's engagement in the Israeli-Palestinian conflict:

We cannot turn our back on Palestine, Palestinians and Gaza. They are asking us "what is Turkey doing in Palestine?" They are asking us "what is the reason behind Turkey's growing interest in the Palestinian cause"... The people who are asking such questions are the ones who do not have any knowledge and conscience on Turkish history. They are not aware of the responsibility that we have to take over and this responsibility has been granted by Turkish history and the will of the Turkish people. ${ }^{53}$

Erdoğan's claim on the constitutive elements of Turkish identity also generated the third, "defender of Islam" role in Turkish foreign policy, which requires a role performance of "defending value systems from attack and undertaking special responsibilities to guarantee ideological purity for a group of states". ${ }^{44}$ Understood as such, the leading cadres of the AKP government identified the Turkish self with the Muslim cause and assumed a responsibility to protect Muslims from any form of violence and repression. Turkey also expressed affinity toward Islamic countries in the region and showed solidarity with their causes, and the implementation of this new policy has inevitably deteriorated its relations with Israel.

The AKP's policies toward Hamas demonstrate this stance well. In 2006, despite criticism from the West and from proWestern Turks, AKP leaders met with the leader of Hamas's military wing, Khaled Mashal, in Ankara, following Hamas's

53 "Erdoğan: Yahudilere Olduğu Gibi Filistin'e de Sahip Çıkıyoruz" [We are protecting the Palestine as we did the Jews], Yeni Şafak. Newspaper, June 13, 2010.

${ }^{54}$ Holsti (1970), p.264. 
Decoding Turkey's Diplomatic Offensive against Israel

victory in the Palestinian legislative elections. ${ }^{55}$ AKP deputies have also been vocal critics of the US presence in Iraq, and have often labeled US incursions in the region "genocide". Additionally, the AKP showed strong affinity with the Palestinian cause, which made a clash with Israel inevitable. During the 2006 summer war between Israel and Hezbollah, for example, "Erdogan lambasted Israel for trying to wipe out the Palestinians in Lebanon". ${ }^{56}$ Moreover, Turkey sided with Hamas during Operation Lead Cast in 2008, hosted Sudanese President Omar Hassan al-Bashir twice in 2008, and voted at the UN Security Council against the USsponsored resolution to impose a new round of sanctions on Iran in June 2010.

The new activism in Turkish foreign policy, which prioritized close relations with radical Islamic states and groups in the Middle East, resulted in the gradual otherization and securitization of Israel. The crisis escalated further after Israel's three-week offensive in the Gaza Strip in December 2008 and January 2009. Turkey's reaction to the Israeli attack was unprecedentedly strong. The magnitude of Turkey's anger became apparent during the Davos Summit of 2009, where Erdoğan participated in a panel discussion with Israeli President Shimon Peres, and accused Peres of "knowing how to kill children well".

The representation of Israel as "murderer" was consistently reproduced in both official and public discourses through repeated articulations. The linguistic and visual representations of Israel as such became so widespread in the public sphere that the meanings

55 Soner Çağaptay, "Secularism and Foreign Policy in Turkey: New Elections, Troubling Trends," Policy Focus (Washington: The Washington Institute for Near East Policy, 2007). http://www.gees.org/documentos/Documen-02212.pdf (accessed on July 12, 2012).

56 Ibid. 
that they produced about Israel came to seem natural and to be the accurate description of reality. For example, the Turkish television series "Separation" shown on TRT, the state-owned TV channel, depicted Israeli soldiers as murderers killing Palestinian civilians, including babies, which caused a strong reaction in Israel.

These representations of Israel that were widely broadcast in the news media and constantly articulated in the official discourse were soon followed by more serious representations that aimed at constructing Israel as a security threat to the region and Turkey's territorial integrity. In a speech during the opening ceremony of TRT's Arabic channel, el-Turkiyya, Erdoğan declared that Israel is the main threat in the region. ${ }^{57}$ During his visit to France in April 2010, Erdoğan again referred to Israel as "the main threat to peace in the Middle East" ${ }^{58}$ In an exchange of words with an Israeli diplomat in South Africa in October 2011, Erdoğan repeated his claim and said that:

You (Israel) used a phosphorus grenade in Gaza. It is a weapon of mass destruction and its use is a crime. You even bombed UN buildings. I now see Israel as a threat for the region because it has an atomic bomb. It does not admit it has the atomic bomb and everybody remains silent on that. But everyone attacks Iran for having the atomic bomb. What kind of justice is this? Israel is an intruder in Gaza and it is committing a state terror. ${ }^{59}$

The construction of Israel as the main security threat for the Middle East also extended to Turkey's domestic politics and led to various attempts to represent Israel as the existential threat

\footnotetext{
${ }^{57}$ Kösebalaban (2010), p.38.

58 "Erdoğan: İsrail Barışın Baş Tehdidi" [Israel is the Main Threat to Peace], Bugün Newspaper, April 7, 2010.

59 "Erdoğan'dan İsrail'e Sert Çıkış" [Erdoğan slams Israel], Hürriyet Newspaper, October 5, 2011.
} 
Decoding Turkey's Diplomatic Offensive against Israel

to Turkey's territorial integrity by linking it with the outlawed Kurdistan Workers' Party (PKK). This new representation started with Hüseyin Çelik's allegation that there might be connection between the Israeli attack on the Mavi Marmara and the PKK's attack on Turkish military units in Iskenderun. The alleged connection between Israel and the PKK found considerable support in pro-government media and the academia in Turkey. Newspapers and TV shows constantly articulated the claim that Israel is supporting the PKK to retaliate Turkey's policies toward Israel. Based on a report by Turkish intelligence agencies, the English version of the Islamist, pro-AKP newspaper, Today's Zaman, for example, wrote that the Herons (unmanned aerial vehicles) operated by Israel were collecting intelligence on Turkish military units in order to aid PKK operations in Hatay and Adana provinces. According to the newspaper, the report also mentioned a captured PKK member who participated in the Iskenderun attack and argued that his repeated trips to Israel reinforced suspicions of a possible link between Israel and the PKK. ${ }^{60}$ Many argued that Israeli military officers had been training PKK terrorists in Northern Iraq. Sedat Laçiner, former head of International Strategic Research Association (USAK) and the current president of Çanakkale University, also wrote about IsraelPKK connection in the daily Star and stated that:

The flirtation between Israel and the PKK turned into a love affair right after Davos, and the cooperation became deepened so much so that it was discussed at the Israeli cabinet. This is because Turkey's defiance of Israel was the biggest possible blow to Israel. Turkey undermined Israel's

60 "Turkish intelligence says Israel's Heron drones give intelligence to PKK militants," Today's Zaman Newspaper, January 17, 2012. http://www.terminalx.org/2012/01/turkish-intelligence-says-israelsheron.html (accessed July 12, 2012). 
legitimacy, and this way punished Israel even more severely than HAMAS did. ${ }^{6}$

It can be argued that the representation of Israel as an existential security threat to Turkey found resonance in opposition political parties and the public at large. Just after the PKK's İskenderun attack, the leader of Republican People's Party (CHP), Kemal Kılıçdaroğlu remarked that "the similarity between the two incidents (i.e., Mavi Marmara and İskenderun attacks) is meaningful". ${ }^{62}$ Additionally, public opinion surveys demonstrate that AKP's efforts to securitize Israel had a convincing impact on Turkish public opinion. ${ }^{63}$ Between October 2004 and August 2009, the percentage of Turkish citizens that perceive an existential threat from Israel increased from 10.20 per cent to 15.64 percent. ${ }^{64}$ According to German Marshall Fund's (GMF) Transatlantic Trends Survey, "the plurality of Turks (48 per cent) are not concerned about Iran acquiring nuclear weapons" that is "in sharp contrast with U.S. (86 per cent) and EU (79 per cent) respondents, where overwhelming majorities were concerned about a nuclear Iran". ${ }^{65}$

${ }^{61}$ Sedat Laçiner, "Israel, Iran, Syria 'Besieging' Turkey by Supporting Kurdish Rebels," Star Newspaper, September 22, 2010.

${ }^{62}$ Quoted in Kösebalaban (2010), p.47.

63 "Poll shows support for government's Israel policy," Today's Zaman Newspaper, September 14, 2011. http://www.todayszaman.com/news256767-poll-shows-support-for-governments-israel-policy.html (accessed June 16, 2012).

64 USAK Dış Politika Algılama Anketi [USAK Foreign Policy Perceptions Survey], 2009. http://www.usak.org.tr/anket.asp?id=25 (accessed June 20, 2012).

65 German Marshall Fund (GMF) Transatlantic Trends Survey, 2010. http://trends.gmfus.org/archives/transatlantic-trends/2010-2/

(accessed July 18, 2012). 
Decoding Turkey's Diplomatic Offensive against Israel

\section{Conclusion}

This paper argued that even though the theory of securitization has developed a provocative framework for analyzing security issues in the post-Cold War world, it remains inadequate in explaining the subjective side of securitization. For the CS, securitization is a speech act and successful securitization requires acceptance of a securitizing move by the audience. Even in democratic societies, leaders can make foreign policy decisions and act without explicit approval of the audience or they can successfully manipulate public opinion through various means at their disposal. They often do this in accordance with their perceptions of the roles -i.e., role conceptions- that their states should play in the international or regional sub-systems. Changes in these role conceptions, we argue, are closely related to long-term foreign policy changes.

The main argument of this paper is that decision makers' threat perceptions are the product of their NRCs, which largely derive from national identity and culture. This does not, however, mean that all foreign policy decisions are subjective phenomena. Objective factors are also important in the process but their effect is more noticeable in the implementation phase, not in the formation of foreign policy preferences.

Recent changes in Turkish foreign policy and the crisis in Turkish-Israeli relations constitute a good case study to test our argument. Turkey and Israel enjoyed very close relations during the Cold War that turned into a strategic partnership in the 1990s. From Turkey's perspective, the main causes of Turkish-Israeli alliance laid in the NRCs of the Kemalist political elite, who chose to distance Turkey from the Middle East. As argued, the official ideology of the Republic provided the framework in which Turkish foreign policy was to be formulated. A shared Western identity 
based on democratic values and secularism and the feeling of being "others" in the Muslim Middle East paved the way for intimate relations between Turkey and Israel. For the Kemalist elite, Turkey's strategic alignment with Israel was mainly an ideological one against the perceived Islamic threat and the radical (Islamic or non-Islamic) regimes in the region. However, the AKP's accession to power after the 2002 elections changed all that. Winning two consecutive elections helped the AKP leaders to eliminate the dominance of the Kemalist elite, including the military, in both domestic and foreign policy and to consolidate their power. The main architects of the new foreign policy had different role and identity conceptions and formulated Turkey's foreign policy in accordance with those conceptions. In the AKP leadership's conceptions, roles such as "regional leader", "protector" and "defender of Islam" included neo-Ottomanist and religious flavors, which required both rapprochement with Islamic and radical Arab countries and at the same time standing up to Israel. The Palestinian issue with its obviously religious essence in this context provided the AKP decision makers an essential tool to act as a countervailing force against Israel. 